\title{
Water Stress Effects on Leaf Growth and Chlorophyll Content but Not the Grain Yield in Traditional Rice (Oryza sativa Linn.) Genotypes of Assam, India II. Protein and Proline Status in Seedlings under PEG Induced Water Stress
}

\author{
Jnandabhiram Chutia ${ }^{1 *}$, Sailen Prasad Borah ${ }^{2}$ \\ ${ }^{1}$ Department of Botany, Darrang College, Tezpur, India; ${ }^{2}$ Department of Botany, Gauhati University, Guwahati, India. \\ Email: *jnan@rediffmail.com
}

Received February $17^{\text {th }}, 2012$; revised March $5^{\text {th }}, 2012$; accepted April $17^{\text {th }}, 2012$

\begin{abstract}
Abiotic stresses can directly or indirectly affect the physiological status of an organism by altering its metabolism, growth, and development. The leaf growth and Chlorophyll content has significantly shown to vary from the control ones while the grain yield was not affected. While many plant species naturally accumulate proline and protein as major organic osmolytes when subjected to different abiotic stresses. These compounds are thought to play adaptive roles in mediating osmotic adjustment and protecting sub cellular structures in stressed plants. Different approaches have been contemplated to increase the concentrations of proline like compounds in plants grown under stress conditions to increase their stress tolerance. Seven different traditional rice varieties of Assam were evaluated for their response to osmolyte production under physiological drought condition through simulation at three levels of osmotic stress of 0.15 bar, 0.25 bar and 0.56 bar of physiological drought initiated by polyethylene glycol (PEG 6000). Along with the evaluation for osmolyte response the different components of genotypic variation for six different drought-sustaining characters in the seven rice varieties were also substantiated. The results indicated that plant height and seed number have significant genotypic coefficient of variability (GCV) and heritability. Verities like Laodubi, Leserihali, Beriabhanga and Borah were screened out as the best drought sustaining variety.
\end{abstract}

Keywords: Abiotic Stresses; Proline; Protein; Osmolyte; Genotypic Coefficient of Variability; Heritability; Traditional Rice Cultivar

\section{Introduction}

Rice genotypes are known to vary widely in their responses to abiotic stresses. About forty-two biotic and abiotic stresses affect rice production [1]. This is in part due to the complexity of interactions between stress factors and various molecular, biochemical and physiological phenomena affecting plant growth and development [2]. Alterations in internal water relations are generally evaluated by investigating the relationships between water potential or its solute and turgor components and relative water content [3].

Simulation of drought stress by polyethylene glycol (PEG) induces drought stress on the plants [4] and significant deviation from the control continues to increase with the increasing solute potential ( $\Psi \mathrm{s})[5]$. PEG-6000

${ }^{*}$ Corresponding author. has long been utilized as a reliable marker under laboratory conditions for testing the drought tolerant genotypes. This is because polyethylene glycol acts as a non-penetrating osmotic agent resulting into increasing solute potential ( $\Psi \mathrm{s})$ and blockage of absorption of water by the root system $[4,6,7]$. Drought screening using some seed technological parameters has been found to be quite useful in a number of crops [8] under laboratory conditions. This technique can be further extended to test drought tolerance in other genotypes, [9].

Length of leaf is negatively related with osmotic stress. Thus the length of the leaf decreases with the rise in solute potential. Reduction in leaf length in higher osmotic stress is due its negative correlation with leaf angle [8]. The longer leaves have wide angle while the shorter ones have smaller angles. The leaf angle is a character usually associated with plasticity in leaf rolling when internal 
water deficit occurs.

Grain yield under stress environment is the primary trait for selection in breeding for drought tolerance. Drought effect on seed yield is due to the relation with duration of watering from flowering until physiological maturity [10].

Osmotic stress generated by polyethylene glycol (PEG-6000) generally reduce photosynthetic rate [11]. Exposure to drought stress leads to a significant effect in Chlorophyll- $a$ and Chlorophyll- $b$ contents [5] .

Response to water stress in plants at the molecular level undoubtedly constitutes an area of major interest for a complete understanding of the process. The major strategy for gaining such understanding is through the approach of proteomics. Differential expression of genes under water stress conditions can reveal a picture as to what are the biochemical pathways that are instrumental in enabling the cells to elicit the right response [12-18]. While there are several reports of expression of a number of genes only under water stress, a much more comprehensive approach is to profile the total protein contents and kinds of protein under normal and stressed conditions.

Many plant species naturally accumulate protein and proline as major organic osmolytes when subjected to different abiotic stresses. These compounds are thought to play adaptive role in mediating osmotic adjustment and protecting sub cellular structures in stressed plants $[19,20]$. Thus, different approaches have been contemplated to increase the concentrations of these compounds in plants grown under stress conditions to increase their stress tolerance. The present investigation, thus is aimed at elucidating the drought sustaining character of some traditional rice cultivars of Assam to drought stress based on some established protocols related to screening of rice cultivars in response to drought stress. Since breeders are still looking for traits that are suitable for screening rice germplasm for characters affecting plant water relations under drought conditions [21].

\section{Materials and Methods}

The present study, initially 12 verities were considered viz., Bengunguti, Beriabhanga, Borah, Jahinga, Kesamani, Kolajoha, Laodubi, Leserihali, Pattesari, Rangadaria, Sakuakumal and Solpuna. After initial studies related to germination index (GI) in PEG initiated drought and the whole plant behaviour under three water regimes then subsequently only seven traditional varieties viz. Laodubi, Borah, Jahinga, Beriabhanga, Pattesari, Leserihali and Kolajoha of Assam, India, were screened for their response to osmolyte production under physiological drought condition simulated by PEG
6000.

Three levels of osmotic potential $(\Psi \pi)$ of 0.15 bar, 0.25 bar and 0.56 bar induced by PEG-6000 were used for simulation of physiological drought. Seeds of the experimental rice varieties were treated with different solutions of PEG-6000. After the PEG-6000 treatment, the germination index was determined and the seedlings were subsequently grown under three different water regimes-1) normal irrigated condition considered as nonstress (control), 2) unirrigated water stress upland condition and 3) unirrigated water stress potted condition.

The experiment was conducted in a randomized block design (RBD) with three replications. Hundred healthy seeds each of the 7 different cultivars was pre soaked in distilled water for $12 \mathrm{hrs}$. Forty eight pairs of clean and sterilized petri plates were used for the experiment. In each replication there were 16 petri plates. The presoaked seeds were first air-dried to eliminate the surface water. They were then placed over blotting paper in the petriplates and were allowed to germinate aseptically under three different osmotic potentials i.e., 0.15 bar, 0.25 bar and 0.56 bar using appropriate concentration of PEG6000 [5]. Deionised water was used for the control and applied similarly. At regular intervals of $12 \mathrm{hrs}, 5-6$ drops of different solutions of PEG-6000 were administered to the seeds in the petri plates. The treated and controlled seeds were allowed to germinate in a BOD incubator at $25^{\circ} \mathrm{C} \pm 2{ }^{\circ} \mathrm{C}$ for seven days. The lid of the petri-plates were opened and replaced for exchange of fresh air to the growing seedlings at regular intervals. The seeds soaked in PEG-6000 solutions were kept under observation for 7 days and the germination index was calculated out. The number of germinating seeds were counted and continued up to seven days at a regular interval of $24 \mathrm{hrs}$.

Collected data were analyzed for determining the 1) seed germination index, 2) leaf protein content and 3) leaf proline content.

The germination index (GI) was calculated by using the formula as suggested by the Association of Official Seed Analysis [22].

$$
\begin{aligned}
\mathbf{G I}= & \frac{\text { No. of germinated Seeds }}{\text { Days of first count }} \\
& +\frac{\text { No. of germinated Seeds }}{\text { Days of Second count }} \\
& +\cdots+\frac{\text { No. of germinated Seeds }}{\text { Days of final count }}
\end{aligned}
$$

The petroleum ether extract of the leaves were prepared and analysed using UV based spectrophotometer (Hitachi grade) at a wavelength of $663 \mathrm{~nm}, 645 \mathrm{~nm}$ and 
Traditional Rice (Oryza sativa Linn.) Genotypes of Assam, India II. Protein and Proline Status in Seedlings under PEG Induced Water Stress

$663 \mathrm{~nm}$. The amount of chlorophyll present in the extract $\mathrm{mg}$ chlorophyll per tissue was calculated out using the following equations:

1) For mg chlorophyll a/g tissue

$$
=12.7\left(\mathrm{~A}_{663}\right)-2.69\left(\mathrm{~A}_{645}\right) \times \frac{\mathrm{V}}{1000 \times \mathrm{W}}
$$

2) For mg chlorophyll b/g tissue

$$
=22.9\left(\mathrm{~A}_{665}\right)-4.68\left(\mathrm{~A}_{645}\right) \times \frac{\mathrm{V}}{1000 \times \mathrm{W}}
$$

3) For total chlorophyll/g tissue

$$
=20.2\left(\mathrm{~A}_{645}\right)+8.02\left(\mathrm{~A}_{663}\right) \times \frac{\mathrm{V}}{1000 \times \mathrm{W}}
$$

where, $\mathrm{A}$ is the absorbance at specific wavelengths; $\mathrm{V}$ is the Final volume of chlorophyll extract in $80 \%$ Acetone and $\mathrm{W}$ is the fresh weight of tissue extract.

For estimation of protein and proline content, young leaves from 20 days old seedlings grown under osmotic potentials of -0.15 bar, 0.25 bar and 0.56 bar were taken. The proline content was assayed by the method described by Bates et al. [23] and Chinard et al. [24]. For the experiment, $0.5 \mathrm{gm}$ of freshly collected leaves were homogenized in $10 \mathrm{ml}$ of $3 \%$ aqueous sulphosalicylic acid. Control sample was consisted of leaves from seedlings grown in deionized water alone. The homogenate was filtered through Whatman No. 2 filter paper. $2 \mathrm{ml}$ of the filtrate was taken in a test tube and $2 \mathrm{ml}$ of glacial acetic acid was added to it. To the mixture freshly prepared 2 $\mathrm{ml}$ of acid ninhydrin was added. The final solution was subjected to heat for $1 \mathrm{hr}$ in a boiling water bath. After one hour of boiling the reaction was terminated by placing the test tube in an ice bath. Now to the test tube $4 \mathrm{ml}$ of toluene was added and stirred for 20 - 30 seconds. Subsequently, the toluene layer was separated and the final mixture was again warmed to room temperature and the red colour (slightly red colour) was measured at 520 $\mathrm{nm}$.

A standard curve was prepared using $0.1,0.2,0.3,0.4$ and $0.5 \mu \mathrm{mol}$ of pure proline and used for conversion of absorbance values into proline content.

Protein content in the leaf samples was determined by following Lowry's method [25].

Proline and protein content were estimated from the seedlings grown under simulated drought condition induced by -0.15 bar, 0.25 bar and 0.56 bar of PEG 6000 . Seeds grown under osmotic stress induced by 0.56 bar of PEG 6000 failed to yield sufficient number of seedlings enough for the biochemical assays. Thus proline and protein could be estimated only in those seedlings grown under 0.15 bar and 0.25 bar of artificial drought.
The genotypic and phenotypic coefficients of variabilities for the characters were calculated according to the formulae of Burton [26]. The heritability in broad sense was estimated according to Johansson et al. [27, 28].

\section{Results and Discussion}

The leaves of modern semi dwarf varieties have relatively small leaves with acute angles often folded into a tube form [29]. In the traditional rice varieties like Laodubi, Leserihali, Pattesari and Beriabhanga, the exceptionally long and droopy leaves with larger leaf angle were more susceptible to rolling due to their ability to intercept relatively more radiant energy, greater extensibility and might help conserved water in plant tissues (Table 1). Chang et al., [30] also worked on rice and advocated the role of larger leaf angle in conservation of water in plant cells. Thus it can be substantiated that long and droopy leaves (i.e., with higher leaf angle) results into leaf rolling decreasing the area intercepting radiation resulting into decrease in rate of transpiration (Gates 1968) as leaf rolling is an adaptive response to water deficit in rice (Singh, 2000).

The present study revealed that the reduction in grain yield was maximum in the variety Laodubi $(23.78 \pm 0.40$ number of grain) under unirrigated potted condition. On the contrary the same variety exhibited a yield of 117.58 \pm 0.30 and $145.81 \pm 0.18$ number of grain under unirrigated upland and irrigated rainfed condition respectively (Table 2). Thus the results indicated that grain yield under stress was limited due to decreased production and translocation of assimilates as the sink size, is not affected (Chaturvadi and Ingram, 1989; Ahmed, 1992). The results clearly indicate that water deficit during booting to anthesis initiation is more detrimental than anthesis stage stress. Ingram, (1989) also reported reduction in grain production due to moisture stress during booting stage to flowering or early grain filling stage in rice. These observations support the hypothesis that selection for yield under reproductive-stage drought stress is effective in rice, and that choice of donor is very important in breeding drought-tolerant rice (Table 3).

In the present investigation there was a significant decrease in the Chlorophyll- $a$ and Chlorophyll- $b$ and total chlorophyll content in the plants of unirrigated upland and potted condition while under normal rained condition the ratios of chlorophyll was higher as evident in Laodubi, Kolajoha and Pattesar (Table 4). An increasing trend of osmotic adjustment $\left(\Delta \psi_{\pi}\right)$ with decreasing solute $\left(\psi_{\mathrm{s}}\right)$ is a mechanism developed for the plant to survive in dry conditions (Heralde, et al., 1998). The higher amount of 


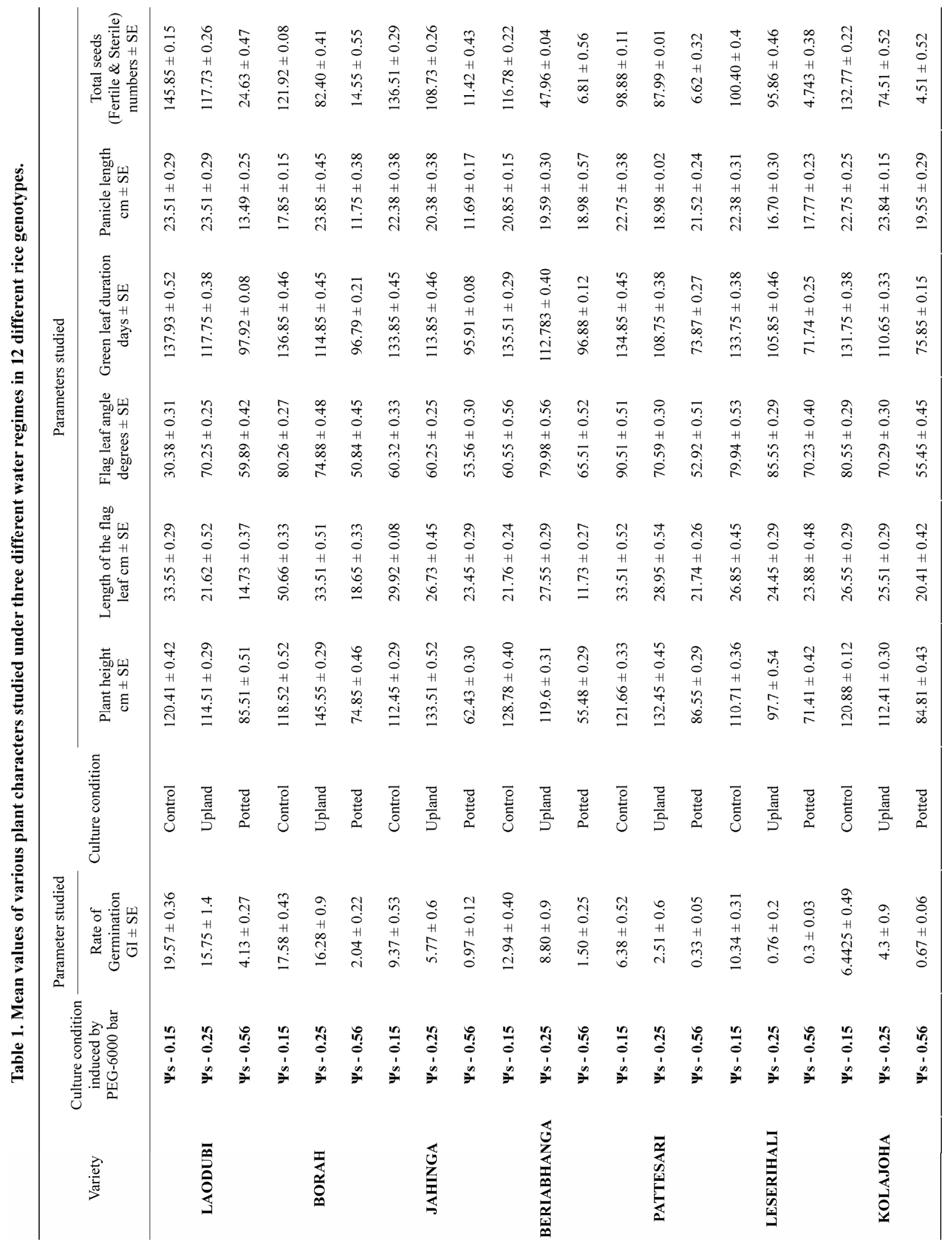


Traditional Rice (Oryza sativa Linn.) Genotypes of Assam, India II. Protein and Proline Status in Seedlings under PEG Induced Water Stress

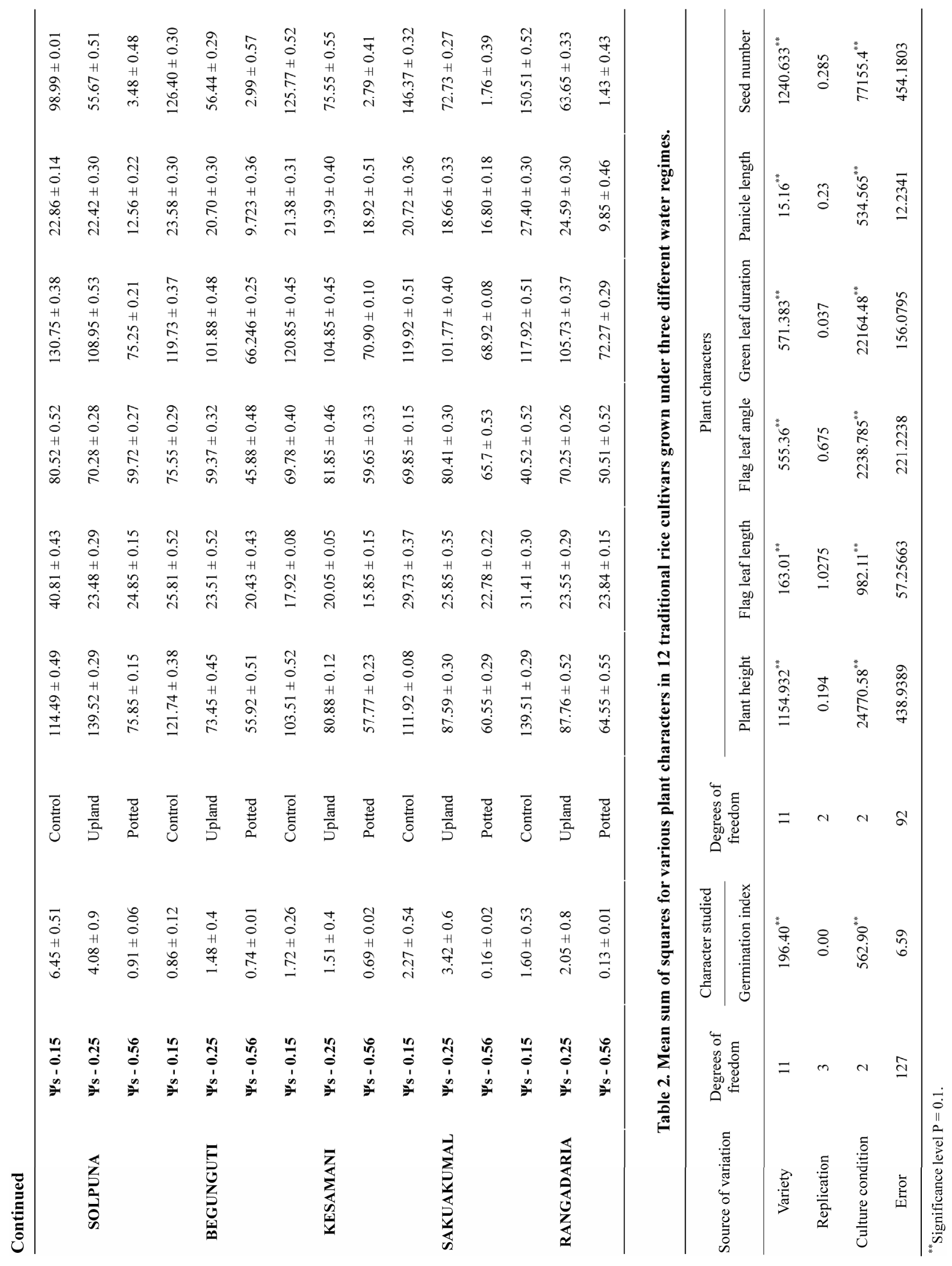


Table 3. Estimates of different genetical parameters in 12 different rice varieties.

\begin{tabular}{|c|c|c|c|c|c|c|c|}
\hline Plant characters & Mean $\pm \mathrm{SE}$ & Range & $\begin{array}{l}\text { Genotypic } \\
\text { variance }\end{array}$ & $\begin{array}{l}\text { Phenotypic } \\
\text { variance }\end{array}$ & $\begin{array}{c}\text { Genotypic } \\
\text { co-efficient of } \\
\text { variability \% }\end{array}$ & $\begin{array}{c}\text { Phenotypic } \\
\text { co-efficient of } \\
\text { variability \% }\end{array}$ & Heritability \% \\
\hline Germination index & 6.276667 & $19.85-0.14$ & 63.26699 & 69.86 & 168.9656 & 177.5532 & 90.56062 \\
\hline Plant height & 99.36111 & $139-56$ & 238.6643 & 677.6032 & 15.5481 & 26.19819 & 35.22184 \\
\hline Flag leaf length & 25.22222 & $51-15$ & 35.25112 & 92.50775 & 29.08998 & 47.12442 & 38.10613 \\
\hline Flag leaf angle & 65.96296 & $80-45$ & 111.3787 & 332.6025 & 15.9993 & 27.64793 & 33.48704 \\
\hline Green leaf duration & 106.01 & $137-66$ & 138.4345 & 294.514 & 11.09886 & 16.18859 & 47.0044 \\
\hline Panicle length & 19.37963 & $24-9$ & 0.975301 & 13.2094 & 5.095934 & 18.75409 & 7.383385 \\
\hline Seed number & 69.96296 & $150-1$ & 262.1508 & 716.3311 & 23.14235 & 38.25505 & 36.59632 \\
\hline
\end{tabular}

Chlorophyll- $a$ and Chlorophyll- $b$ attributes to the accumulation of solutes in the cell sap through passive accumulation resulting from reduced cell size (Morgan, 1984) which significantly does osmotic adjustment $\left(\Delta \psi_{\pi}\right)$. Non-stomatal restrictions on $\mathrm{CO}_{2}$ assimilation under drought stress can be effectively assessed through measuring Chlorophyll based parameters. Energetic status of the chloroplast increases as a consequence of the drought stress which has a direct relationship to that of increased amount of total chlorophyll and Chl $a$ and Chl $b$ [5] among the stressed induced verities.

Germination and seedling development under laboratory conditions have been accepted as suitable growth stages for testing the response to abiotic stresses [31] and thus it was employed to evaluate the drought sustaining character of the local varieties of Assa. A positive correlation between germination index (GI) in PEG initiated drought and the whole plant behaviour under three water regimes were observed in the present investigation (Table 2). This was evident from the results exhibited by Laodubi, Leserihali and Pattesari with higher germination index while these same varieties showed good response to other drought sustaining characters under three water regimes. Thus the determination of germination index (GI) can be used just as an easy and reliable parameter for measuring drought sustenance among the traditional rice cultivars of Assam.

The low germination rate in Jahinga, Pattesari and Kolajoha as observed in the present study was due to the osmotic stress induced by PEG 6000 which had mark effect in both shoots and roots parameters. The reduction in seed germination may be due to the less availability of free water to the seeds during early hours of inbibition, thus leaving the hydrolytic enzymes inactive [32,33]. Inhibition of germination at higher osmotic potential may possibly be attributed to moisture deficit in the seed below the threshold requirement for germination [34]. The reduction in shoot and root growth is important as PEG induced stress affects root volume and root length [10]. The reduction of root volume under induced osmotic stress originates not only from growth inhibitions but also from a loss of turgidity [35].

Total protein content decreases due to abiotic stress Baruah et al. [36]. As synthesis of proteins occur during dehydration stress a class of proteins called late embryogenesis abundant globular protein known as osmotin or dehydrin [19] are known to accumulate in dry seeds, which play an important role in the regulation of dehydration in seeds. The protein content among all tolerant genotypes was found higher than susceptible ones [37]. Water stress condition caused a marked change in protein synthesizing apparatus of plant tissue [38] and the capacity for protein synthesis also decreases considerably as observed in response to water stress [39]. In the present study the results obtained with higher protein content in Borah, Beriabhanga, Laodubi and Solpuna (Table 5) are in agreement with the findings of Chinoy et al. [40] who also reported a high protein content in drought stressed rice plant. Ashraf and Foolad [20] had reported that higher protein content in tolerant genotypes under water stress condition is due to higher DNA and RNA content, which stimulate synthesis and inhibit protein decomposition.

Decrease in osmotic potential under stress reflects the increased hydrolysis of macromolecules into simpler ones like mono- and disaccharides, amino acids specially proteins etc. and consequently higher osmolite concentration [41]. Thus under higher solute potential, Laodubi, Leserihali, Beriabhanga and Pattesari accumulated higher proline (Table 6), which acted as a osmoticum and accounted for higher drought tolerance due to greater relative water content and leaf water potential [42]. This is because proline is a major organic osmolyte that accumulates in a variety of plant species in response to environmental stresses such as drought which is thought to have positive effects on enzyme and membrane integrity 
Traditional Rice (Oryza sativa Linn.) Genotypes of Assam, India II. Protein and

Proline Status in Seedlings under PEG Induced Water Stress

Table 4. Chlorophyll content in 12 different rice varieties grown under three different water regimes.

\begin{tabular}{|c|c|c|c|c|c|}
\hline \multirow[b]{2}{*}{ S1. No. } & \multirow[b]{2}{*}{ Variety } & \multirow{2}{*}{$\begin{array}{l}\text { Culture } \\
\text { condition }\end{array}$} & \multicolumn{3}{|c|}{ Amount of chlorophyll } \\
\hline & & & $\begin{array}{l}\text { CHL. a/g } \\
\text { tissue }\end{array}$ & $\begin{array}{l}\mathrm{Chl} \mathrm{b/g} \\
\text { tissue }\end{array}$ & $\begin{array}{c}\text { Total } \\
\text { chlorophyll }\end{array}$ \\
\hline \multirow{3}{*}{1} & \multirow{3}{*}{ Laodubi } & Control & 12.39 & 10.39 & 9.17 \\
\hline & & Upland & 6.870 & 5.541 & 4.88 \\
\hline & & Potted & 5.53 & 4.831 & 4.26 \\
\hline \multirow{3}{*}{2} & \multirow{3}{*}{ Borah } & Control & 8.06 & 6.34 & 5.59 \\
\hline & & Upland & 8.45 & 7.02 & 6.20 \\
\hline & & Potted & 7.20 & 6.82 & 6.02 \\
\hline \multirow{3}{*}{3} & \multirow{3}{*}{ Jahinga } & Control & 30.89 & 22.78 & 20.13 \\
\hline & & Upland & 16.76 & 3.15 & 2.78 \\
\hline & & Potted & 12.28 & 2.79 & 2.46 \\
\hline \multirow{3}{*}{4} & \multirow{3}{*}{ Beriabhanga } & Control & 21.48 & 17.58 & 15.51 \\
\hline & & Upland & 18.26 & 15.98 & 14.10 \\
\hline & & Potted & 17.04 & 13.46 & 11.87 \\
\hline \multirow{3}{*}{5} & \multirow{3}{*}{ Pattesari } & Control & 18.19 & 13.92 & 12.28 \\
\hline & & Upland & 5.44 & 4.67 & 4.12 \\
\hline & & Potted & 4.81 & 4.44 & 3.919 \\
\hline \multirow{3}{*}{6} & \multirow{3}{*}{ Leserihali } & Control & 24.23 & 19.348 & 17.07 \\
\hline & & Upland & 7.911 & 11.128 & 9.81 \\
\hline & & Potted & 7.175 & 8.815 & 7.77 \\
\hline \multirow{3}{*}{7} & \multirow{3}{*}{ Kolajoha } & Control & 6.65 & 5.33 & 4.70 \\
\hline & & Upland & 2.42 & 2.15 & 1.89 \\
\hline & & Potted & 1.24 & 1.46 & 1.29 \\
\hline \multirow{3}{*}{8} & \multirow{3}{*}{ Solpuna } & Control & 6.65 & 5.33 & 4.70 \\
\hline & & Upland & 2.42 & 2.15 & 1.89 \\
\hline & & Potted & 1.24 & 1.46 & 1.29 \\
\hline \multirow{3}{*}{9} & \multirow{3}{*}{ Bengunguti } & Control & 6.48 & 4.58 & 6.70 \\
\hline & & Upland & 8.26 & 5.98 & 4.10 \\
\hline & & Potted & 7.04 & 3.46 & 1.87 \\
\hline \multirow{3}{*}{10} & \multirow{3}{*}{ Kesamani } & Control & 1.02 & 1.76 & 3.04 \\
\hline & & Upland & 4.46 & 6.08 & 7.13 \\
\hline & & Potted & 4.36 & 6.36 & 5.61 \\
\hline \multirow{3}{*}{11} & \multirow{3}{*}{ Sakuakumal } & Control & 8.19 & 3.92 & 2.28 \\
\hline & & Upland & 5.44 & 4.67 & 4.12 \\
\hline & & Potted & 4.81 & 4.44 & 3.91 \\
\hline \multirow{3}{*}{12} & & Control & 8.19 & 3.92 & 2.28 \\
\hline & Rangadaria & Upland & 5.44 & 4.67 & 4.12 \\
\hline & & Potted & 4.81 & 4.44 & 3.91 \\
\hline
\end{tabular}

along with adaptive roles in mediating osmotic adjustment in plants grown under stressed conditions. Exogenous application of proline to plants, before, during, or after stress exposure, has been shown to increase the internal levels of these compounds and generally enhances plant growth and final crop yield under stress conditions [20]. This can be also summed up that over all water loss causes increase in concentration of solutes leading to high concentration of cell sap and intercellular fluid causes a greater decrease in the water potential of the fluids. This causes stress on the protoplasm [43].

Tolerance to abiotic stresses is very complex at the whole plant and cellular levels [44-47]. Putting these observations under consideration the subsequent phases of analysis was done so as to establish the complexity of

Table 5. Total leaf protein content (mg/g of leaf tissue) in 7 different rice cultivars grown under simulated physiological drought stress condition.

\begin{tabular}{ccccc}
\hline & & \multicolumn{3}{c}{ Culture condition } \\
\cline { 3 - 5 } Sl. No & Variety & $\begin{array}{c}\text { Control } \\
\text { (deionized } \\
\text { water) }\end{array}$ & $\begin{array}{c}\text { Simulated } \\
\text { osmotic } \\
\text { drought of } \\
0.15 \text { bar }\end{array}$ & $\begin{array}{c}\text { Simulated } \\
\text { osmotic } \\
\text { drought of } \\
0.25 \text { bar }\end{array}$ \\
\hline 1 & Laodubi & 0.12 & 0.16 & 0.15 \\
2 & Borah & 0.15 & 0.18 & 0.14 \\
3 & Jahinga & 0.12 & 0.19 & 0.15 \\
4 & Beriabhanga & 0.11 & 0.21 & 0.15 \\
5 & Pattesari & 0.119 & 0.18 & 0.13 \\
6 & Leserihali & 0.15 & 0.19 & 0.12 \\
7 & Kolajoha & 0.12 & 0.16 & 0.11 \\
\hline
\end{tabular}

Table 6. Proline content ( $\mu \mathrm{mol} / \mathrm{g}$ of leaf tissue) in 7 different rice cultivars grown under simulated physiological drought stress.

\begin{tabular}{ccccc}
\hline & & \multicolumn{3}{c}{ Culture condition } \\
\cline { 3 - 5 } Sl. No & Variety & $\begin{array}{c}\text { Control } \\
\text { (deionized } \\
\text { water) }\end{array}$ & $\begin{array}{c}\text { Simulated } \\
\text { osmotic } \\
\text { drought of } \\
0.15 \text { bar }\end{array}$ & $\begin{array}{c}\text { Simulated } \\
\text { osmotic } \\
\text { drought of } \\
0.25 \text { bar }\end{array}$ \\
\hline 1 & Laodubi* $^{* *}$ & 0.003 & 0.132 & 0.253 \\
2 & Borah $^{* *}$ & 0.001 & 0.0131 & 0.161 \\
3 & Jahinga $^{* * *}$ & 0.0003 & 0.173 & 0.145 \\
4 & Beriabhanga $^{* *}$ & 0.061 & 0.068 & 0.171 \\
5 & Pattesari $^{*}$ & 0.069 & 0.079 & 0.135 \\
7 & Leserihali $^{* *}$ & 0.057 & 0.053 & 0.204 \\
\hline
\end{tabular}

${ }^{* *}$ Varieties selected as the best performing ones. 
Table 7. Estimates of different genetical parameters in 7 different rice varieties.

\begin{tabular}{|c|c|c|c|c|c|c|c|}
\hline Plant characters & Mean $\pm \mathrm{SE}$ & Range & $\begin{array}{l}\text { Genotypic } \\
\text { variance }\end{array}$ & $\begin{array}{l}\text { Phenotypic } \\
\text { variance }\end{array}$ & $\begin{array}{l}\text { Genotypic } \\
\text { co-efficient of } \\
\text { variability } \\
\text { GCV \% }\end{array}$ & $\begin{array}{l}\text { Phenotypic } \\
\text { co-efficient of } \\
\text { variability } \\
\text { PCV \% }\end{array}$ & Heritability $\%$ \\
\hline Plant height & 107.4286 & $129-55$ & 40427.44 & 40521.63 & 187.16 & 187.38 & 99.76 \\
\hline Flag leaf length & 26.44444 & $50-11$ & 55.09 & 77.91 & 28.06 & 10.31 & 70.71 \\
\hline Flag leaf angle & 65.38095 & $90-51$ & 104.53 & 219.88 & 15.63 & 22.68 & 47.54 \\
\hline Green leaf duration & 111.3016 & $138-73$ & 87.65 & 109.26 & 8.41 & 9.39 & 80.23 \\
\hline Panicle length & 19.5873 & $24-11$ & 4.49 & 11.41 & 10.83 & 17.25 & 39.39 \\
\hline Seed number & 70.80952 & $146-5$ & 649.40 & 769.26 & 35.99 & 39.17 & 84.42 \\
\hline
\end{tabular}

interactions between stress factors and various molecular, biochemical and physiological phenomena affecting plant growth and development [2]. In correlation to this it has been observed that the different components of genotypic variation for six drought-sustaining characters in seven experimental rice varieties indicates that plant height and seed number have less environmental influences with high GCV as 187.16 and 35.99 respectively with high heritability (Table 7).

From this screening procedure it has been Laodubi, Leserihali, Beriabhanga and Borah cultivars were screened out as the best drought sustaining variety among the ones considered in this investigation. This paves the way for further investigation into the inherent characters of drought sustenance characters of the traditional cultivars of Assam.

\section{REFERENCES}

[1] R. K. Sarkar, J. N. Reddy, S. G. Sharma and M. I. Abdelbagi, "Physiological Basis of Submergence Tolerance in Rice and Implication for Crop Improvement," Current Science, Vol. 9, No. 7, 2006, pp. 899-906.

[2] J. K. Zhu, "Salt and Drought Stress Signal Transduction in Plants," Annual Review of Plant Physiology and Plant Molecular Biology, Vol. 53, 2002, pp. 247-273.

[3] J. M. Cutler, K. W. Sahan and P. L. Steponkus, "Alteration of the Internal Water Relations of Rice in Response to Drought Hardening," Crop Science, Vol. 20, No. 3, 1980, pp. 307-310. doi:10.2135/cropsci1980.0011183X002000030004x

[4] Y. Jiang, S. E. Macdonald and J. J. Zwiazak, "Effects of Cold Storage and Water Stress on Water Relations and Gas Exchange of White Spruce (Picea glauca) Seedlings," Tree Physiology, Vol. 15, No. 4, 1995, pp. 267273.

[5] A. Ranjbarfordoei, R. Samson, P. V. Damne and R. Lemeur, "Effects of Drought Stress Induced by Polyethylene Glycol on Pigment Content and Photosynthetic Gas Ex- change of Pistacia khinjuk and P mutica," Photosynthetic, Vol. 38, No. 3, 2000, pp. 443-447. doi:10.1023/A:1010946209484

[6] O. Chezen, W. hartwig and P. M. Newman, "The Different Effects of PEG-6000 and $\mathrm{NaCl}$ on Leaf Development Are Associated with Differential Inhibition of Root Water Transport," Plant Cell, Vol. 18, No. 7, 1995, pp. 727-735. doi:10.1111/j.1365-3040.1995.tb00575.x

[7] M. Ashraf and J. W. O'Leary, "Effect of Drought Stress on Growth, Water Relations and Gas Exchange of Two Lines of Sunflower Differing in Degree of Salt Tolerance," International Journal of Plant Sciences, Vol. 157, No. 6, 1996, pp. 729-732.

doi: $10.1086 / 297395$

[8] K. Singh and B. S. Afria, "Seed Technological Approach for Evaluation of Drought Tolerance in Wheat Germplasm," In: T. P. Yadav and C. Ram, Eds., Proc. Nation Semin. Seed Sci Tech, HAU, Hissar, 1988, pp. 72-178.

[9] K. Singh and B. L. Kakralya, "Seed Physiological Approach for Evaluation of Drought Tolerance in Groundnut Stress and Environmental Plant Physiology," In: K. K. Bora, K. Singh and A. Kumar, Eds., Pointer Publishers, Jaipur, Rajasthan, 2001, pp. 45-152.

[10] M. El. Midaoui, H. Serieys and F. Kaan, "Effects of Osmotic and Water Stresses on Root and Shoot Morphology and Seed Yield in Sunflower (Helianthus annuus L.) Genotypes Breed for Morocco or Issued from Introgression with $H$. argophyllus T. \& G. and $H$. debilis Nutt," HELIA, Vol. 26, Nr. 38, 2003, pp. 1-16.

[11] J. Zhang and M. B. Kirkham, "Water Relations of Water Stressed Split Root C4 and C3 Plants," American Journal of Botany, Vol. 82, No. 10, 1995, pp. 1220-1229. doi: $10.2307 / 2446244$

[12] N. Holmberg and L. Bulow, "Improving Stress Tolerance in Plant by Gene Transfer," Trends in Plant Science, Vol. 3, No. 2, 1998, pp. 61-66. doi:10.1016/S1360-1385(97)01163-1

[13] M. Kasuga, W. Liu, S. Miura, K. Yamaguchi-Shinozaki and K. Shinozaki, "Improving Plant Drought, Salt, and Freezing Tolerance by Gene Transfer of a Single StressInducible Transcription Factor," Nature Biotechnology, 
Traditional Rice (Oryza sativa Linn.) Genotypes of Assam, India II. Protein and Proline Status in Seedlings under PEG Induced Water Stress

Vol. 17, 1999, pp. 287-291. doi:10.1038/7036

[14] R. Serrano, F. A. Culianz-Macia and V. Moreno, "Genetic Engineering of Salt and Drought Tolerance with Yeast Regulatory Genes," Scientia Horticulturae, Vol. 78, No. 1-4, 1999, pp. 261-269. doi:10.1016/S0304-4238(98)00196-4

[15] P. M. Hasegawa, R. A. Bressan, J. K. Zhu and H. J. Bohnert, "Plant Cellular and Molecular Responses to High Salinity," Annual Review of Plant Physiology and Plant Molecular Biology, Vol. 51, 2000, pp. 463-499. doi:10.1146/annurev.arplant.51.1.463

[16] J. K. Zhu, "Plant Salt Tolerance," Trends in Plant Science, Vol. 6, No. 2, 2001, pp. 66-71. doi:10.1016/S1360-1385(00)01838-0

[17] V. Prabhavathi, J. S. Yadav, P. A. Kumar and M. V. Rajam, "Abiotic Stress Tolerance in Transgenic Eggplant (Solanum melongena L.) by Introduction of Bactrial Mannitol Phophodehydrogenase Gene," Molecular Breeding, Vol. 9, No. 2, 2002, pp. 137-147. doi:10.1023/A:1026765026493

[18] D. Rontein, G. Basset and A. D. Hanson, "Metabolic Engineering of Osmoprotectant Accumulation in Plants," Metabolic Engineering, Vol. 4, No. 1, 2002, pp. 49-56. doi:10.1006/mben.2001.0208

[19] D. P. Singh, "Water Deficit Stress in Stress Physiology," New Age Publishers, New Delhi, 2003, pp. 64-79.

[20] M. Ashraf and M. R. Foolad, "Role of Glycine Betaine and Proline in Improving Plant Abiotic Stress Resistance," Environmental and Experimental Botany, Vol. 59, No. 2, 2007, pp. 206-216. doi:10.1016/j.envexpbot.2005.12.006

[21] B. N. Jha and R. A. Singh, "Physiological Responses of Rice Varieties to Different Levels of Moisture Stress," Plant Physiology, Vol. 2, No. 1, 1997, pp. 81-84.

[22] Association of Official Seed Analysis (AOSA), "Seed Vigor Testing Handbook," Contribution No. 32 to the handbook on Seed Testing, 1983.

[23] L. S. Bates, R. P. Walden and I. D. Teare, "Rapid Determination of Free Proline for Water-Stress Studies," Plant and Soil, Vol. 39, No. 1, 1973, pp. 205-207. doi:10.1007/BF00018060

[24] E. P. Chinard, The Journal of Biological Chemistry, Vol. 199, 1952, p. 91.

[25] O. H. Lowry, N. J. Rosenbrough, A. L. Farr and R. J. Randall, "Protein Measurement with Folin Phenol Reagent," The Journal of Biological Chemistry, Vol. 193, No. 1, 1951, pp. 265-275.

[26] G. W. Burton, "Quantitative Inheritance in Grasses," Proceedings of 6th Intern, Grasslands Congress, Vol. 1, 1952, pp. 277-283.

[27] H. W. Johnson, C. L. Haward and A. R. Khan, "Genotypic, Phenotypic Correlations in Soyabean and Their Implication in Selection," Agronomy Journal, Vol. 47, No. 10,1955 , pp. $477-483$. doi:10.2134/agronj1955.00021962004700100008x
[28] H. W. Johnson, H. F. Robinson and R. E. Comstock, "Estimates of Genetic and Environmental Variability in Soyabean," Agronomy Journal, Vol. 47, No. 7, 1955, pp. 314-318. doi:10.2134/agronj1955.00021962004700070009x

[29] N. C. Turner, "Role of Shoot Characteristics in Drought Resistance of Crop Plants," In: Drought Resistance in Crops with Emphasis on Rice, IRRI, 1982, pp. 115-134

[30] T. T. Chang, G. C. Loresto and O. Tagumpay, "Screening Rice Germplasm for Drought Resistance," Sabard Journal, Vol. 6, 1974, pp. 9-16.

[31] Sharif-zadeh and J. Mohsen, "Influence of Priming Techniques on Seed Germination Behavior of Maize Inbreed Lines (Zea mays L.)," Journal of Agricultural and Biological Science, Vol. 3, No. 3, 2008, pp. 22-25.

[32] C. B. Shah and R. S. Loomis, "Ribonucleic Acid and Protein Metabolism in Sugar Beet during Drought," Plant Physiology, Vol. 18, 1975, pp. 240-254.

[33] A. Hadas, "Water Uptake and Germination of Leguminous Seeds under Changing External Water Potential in Osmoticum Solution," Journal of Experimental Botany, Vol. 27, No. 3, 1976, pp. 480-489. doi: $10.1093 / \mathrm{j} \times \mathrm{b} / 27.3 .480$

[34] J. H. Everiff, "Seed Germination Characteristics of Three Weedy Plants Species from South Taxas," Journal of Range Management, Vol. 36, No. 2, 1983, pp. 246-249. doi: $10.2307 / 3898175$

[35] M. G. Huck, B. Kleper and M. M. Taylor, "Diurnal Variation in Root Diameter," Plant Physiology, Vol. 45, No. 4, 1970, pp. 529-530. doi:10.1104/pp.45.4.529

[36] K. K. Baruahand, K. Singh and A. Kumar, "Evaluation of Drought Tolerance in Groundnut Stress and Environmental Plant Physiology," Pointer Publishers, Jaipur, Rajasthan, 1998, pp. 145-152.

[37] R. Serraj and T. R. Sinclair, "Osmolyte Accumulation: Can It Really Help Increase Crop Yield under Drought Conditions?" Plant, Cell \& Environment, Vol. 25, No. 2, 2002, pp. 333-341. doi:10.1046/j.1365-3040.2002.00754.x

[38] P. A. Genkel, N. A. Satarova and E. K. Tvorus, "Effect of Drought on Protein Synthesis and the State of Ribosomed in Plants," Fiziol, Rast., Vol. 14, 1967, pp. 898-907.

[39] T. C. Hsiao, "Rapid Changes in the Levels of Polyribosomes in Zea mays in Reponse to Water Stress," Plant Physiology, Vol. 46, No. 2, 1970, pp. 281-285. doi: $10.1104 / p p .46 .2 .281$

[40] J. J. Chinoy, Y. D. Singh and K. Gurumurti, "Biosynthesis of Ascorbic Acid and Mobilization Patterns of Macromolecules during Water Stressing Germinating Ciser Seedling," Biology Plant (Prague), Vol. 16, 1974, pp. 301-307.

[41] A. Tyagi, N. Kumar and R. K. Sairam, "Efficacy of RWC, Membrane Stability, Osmotic Potential, Endogenous ABA and Root Biomass as Indices for Selection against Water Stress in Rice," Indian Journal of Plant Physiology, Vol. 4, No. 4, 1999, pp. 302-306. 
[42] K. K. Baruah, S. S. Bhuyan, T. J. Ghosh and A. K. Pathak, "Response of Rice Genotypes to Moisture Stress Imposed at Seedling Stage," Indian Journal of Plant Physiology, Vol. 3, No. 3, 1998, pp. 181-184.

[43] A. H. Bunting and A. H. Kasam, "Principles of Crop Water Use, Dry Matter Production That Govern Choice of Crops and Systems," In: F. R. Bidinger and C. Johansen, Eds., Drought Research Priorities for the Dryland Tropics, ICRISAT, Pathancheru, 1988, pp. 43-61.

[44] M. R. Foolad, "Comparison of Salt Tolerance during Seed Germination and Vegetative Growth in Tomato by QTL Mapping," Genome, Vol. 42, No. 4, 1999, pp. 727734. doi:10.1139/g98-163
[45] M. R. Foolad, P. Subbiah, C. Kramer, G. Hargrave and G. Y. Lin, "Genetic Relationships among Cold, Salt and Drought Tolerance during Seed Germination in an Interspecific cross of Tomato," Euphytica, Vol. 130, No. 2, 2003, pp. 199-206. doi:10.1023/A:1022871500583

[46] M. R. Foolad, L. Zhang and P. Subbiah, "Genetics of Drought Tolerance during Seed Germination in Tomato: Inheritance and QTL Mapping," Genome, Vol. 46, No. 4, 2003, pp. 536-545. doi:10.1139/g03-035

[47] M. Ashraf and P. J. C. Harrish, "Potential Biochemical Indicators of Salinity Tolerance in Plants," Plant Science, Vol. 166, No. 1, 2004, pp. 3-16. doi:10.1016/i.plantsci.2003.10.024 